\title{
コミュニケーションロボットの 社会実装にむけた研究と開発
}

\author{
久保田 直行*
}

\section{1. はじめに}

近年, 多種多様なスマートスピーカーが発売されている。話 しかけるだけで，天気やニュースを伝えてくれるだけでなく， 音楽の再生や家電の操作なども簡単に行えるようになった. 我々は，スマートスピーカーが実行できる機能を知っているた め，それにあわせた会話を試みるが，その機能に限定すれば, まるでチューリングテスト $[1,2]$ をパスしているようにも思 えてくる.チューリングは, 「計算機構と知能」の論文の中で, チューリングテストに合格すれば, 機械が知能を持っていると 定義したが, 電話での自動音声案内, スマートデバイスの音声 アシスタント機能, スマートスピーカーとのやりとりのよう に，機械との音声コミュニケーションがますます身近な存在に なるにつれ，機械が話しているときは静かに待ち，一呼吸あけ てから話しかけ, そして機械からの返答を少し待つというター ンティキングのタイミングの取り方と時間的な遅延にも慣れて きた。必要な情報を得るための多少の待ち時間は, 許せてしま う. 一方, 最近の SNS (social networking service) でのやりと りでは，時間との戦いが繰り広げられている。瞬で「既読」 がつき, その後, 直ちに返信が来る. 10 分も放置していると, 催促が来てしまう。そして，たかだか 10 分しか経っていない のにもかかわらず,「遅くなってごめん」と書いた上で，たわい もない雑談を続ける. 色々な意味でフェーストゥフェースのコ ミュニケーションとの違いにも慣れてきたが, 思い返せば, 電 子メールが普及してきた頃, 「電子メールは電話と異なり, 相 手の時間を気にせず，自分も時間を選べるので便利」と言われ ていたことを懐かしく感じる.

さて，コミュニケーションロボットとのやりとりは，どうで あろうか. 情報支援や家電操作支援に関する機能のみを必要と するユーザにとっては，スマートスピーカーやスマートデバ イスで十分であろう。我々は, コミュニケーションロボットに 何を期待し, どのような機能を必要としているのか, コミュニ ケーションロボットの市場と動向を概観してみる.

国際ロボット連盟は「2018 年度 World Robotics Report」 [3] において，2017 年のサービスロボットの世界における売上高

\footnotetext{
$\dagger \quad$ Research and Development Towards Social Implementation of Communication Robots

Naoyuki KUBOTA

* 首都大学東京大学院 システムデザイン研究科

Graduate School of Systems Design, Tokyo Metropolitan University
}

が前年に比べ 39\% 増加し, 66 億米ドルに達し, 販売台数も $85 \%$ 増加したと発表している. エンターテイメントロボット などの個人用サービスロボットは，25\% 増の 850 万台が販売 され, 今後も順調に増加すると見込まれている。経済産業省の 「ロボット産業市場動向調査結果」 [4]によると, 2025 年には, 日本のサービス分野における将来のサービスロボットの市場規 模が全体の $50 \%$ となる 2.6 兆円になると予測している.この ようにサービスロボットへの期待が高まる中, IDC Japan 株式 会社が 2018 年に発表した「国内サービスロボット／ドローン ユーザー利用動向調査結果」[5]によると, サービスロボット の活用領域は,「受付／案内／接客」が $34.8 \%$ で最も高く, 顧 客と対話するコミュニケーションロボットへの需要が高い. ま た, 2018 年に開発されたサービスロボットの動向に関する調 査結果 [6] では, ホビー $(17.9 \%)$, 教育 $(15.4 \%)$, 見守り・コ ミュニケーション $(8.9 \%)$, アミューズメント $(7.7 \%)$, 家事 支援 $(5.8 \%)$, 案内受付 $(5.1 \%)$ と続き, ロボットのコミュニ ケーションに関する機能への需要は高い.

現在, 業務の高コスト構造を改善するために, 業務を行う口 ボットだけでなく，機能（サービス）を提供する制御用ソフ トウェアをクラウド経由で貸し出す RaaS（Robot（あるいは, Robotics）as a Service）に関する事業が普及し始めている [7]. RaaS では, ロボットの稼働状況などもクラウド上で管理でき るため, ロボットの台数や使用量, 使用時間などにあわせた課 金の仕組みを提供でき, 初期導入費なしにロボットを提供す るビジネスも展開されている.また, RaaSでは, 人間とのコ ミュニケーションに必要な音声・画像処理機能をクラウド上の 深層学習を用いて実装でき, 各種設定もロボット上で行うので は無く, クラウド上でできるため, 専門知識の無いユーザーも 容易に利用できる点も普及に貢献している.

以上のように, コミュニケーションロボットへの需要はます ます高まっており，人間のような自然なコミュニケーション を実現するためのシステム開発も盛んに行われている。実際, 様々なチャットボットが開発され $[8,9]$, リアルな実体を持つ コミュニケーションロボットにも容易に実装できるようになっ た. 仮想空間上のチャットボットとの大きな違いは, コミュニ ケーションロボット自体が我々人間の存在を認識し, 我々が 見ている世界をも認識していると感じさせてしまう点である. その結果, ロボットとのコミュニケーションにおいて, 人間が 使っている言語ラベルとしての記号と実世界の意味を結びつけ ること (シンボルグラウンディング問題への対処),「わかる」 
ことを期待してしまう。掕らく，スマートスピーカーやス マートデバイスには期待しないであろう

本稿では，まず，RaaSを中心としたコミュニケーションロ ボットに関する研究開発の現状について簡単に紹介する。次 に, 我々人間が行っているコミュニケーションについて説明し た上で，コミュニケーションロボットに求められる能力につい て考える. 最後に，コミュニケーションロボットとの未来につ いて展望する。

\section{2. コミュニケーションするロボット}

\section{1 コミュニケーションロボットの社会実装}

近年のコミュニケーションロボットの多くは, 音声・画像認識 などの機能をクラウドシステムに頼っている．Cyber-Physical System（CPS）では，物理世界のデー夕をIoT デバイスなどで 計測・収集し, 仮想世界上のビッグデータを解析・学習した上 で，それらの結果を物理世界での制御やサービスにフィード バックする [10]. RaaS は，まさにCPS を具現化している.

国内における RaaS の先駆的事例であるソフトバンクロボ ティクスの Pepperの法人モデル「Pepper for Biz」 [11] の導入 企業数は, 2018 年 10 月現在, 2000 社を超えたという. Pepper for Biz 基本プランでは，業界にあわせた会話や動きを設定し た 200 テンプレートが用意され，誰でも簡単にアプリケーショ ンを作成することができ，さらに，必要にあわせて，顧客への クーポンの配信や写真撮影などのサービスなど，様々なサー ビスをインテグレーションすることができる，例えば，山口 ら [12]は，これらのサービスを用いて，各種センサによる性別 や年齢の推定，さらに表情変化を利用した商品推薦を行うとと もに，インタラクションによる客のニーズ収集に向けた実証実 験を行っている（図 1)

海外での RaaS の例として, Aeolus Robotics 社の「アイオロ ス・ロボット」 [13] のレンタルサービスが 2019 年に開始され る予定である。クラウドではなくロボット内に高度な物体検 知・空間認識・生体信号検知機能が実装され，介護施設内の監 視や日用品の運搬といった介護士の業務サポートを行うことを 目的に開発され，空港・ホテル・レストラン・病院などの公共 施設内のパトロールや配達業務にも展開される予定である.

富士ソフト社の PALRO [14] は，できる限り，PALRO 内で 音声対話などの基本処理を行っているが，クラウドサービス との連携も進んでおり，現在，多くの高齢者施設などで用いら れている。レクリエーションのコンテンツが豊富で, 1 年間を 通して，様々なエンターテイメントを提供する。例えば，大保 らは, PALROの多様なコミュニケーション機能を活かして, ショッピングセンターを対象とした情報推薦に関する実証実験 を行っている [15]

Double Robotics 社の Double [16] は，人間との直接的なコ ミュニケーションを対象とはせず，人と人を繋げるインタ フェースとなるテレイグジスタンスの環境を提供する。また, オリイ研究所 [17] は, 孤独の要因となる移動・対話・役割な どの問題を解決し，これからの時代の新たな「社会参加」を実 現するために, OriHimeや OriHime-D を開発した. OriHime は，「その場にいる」ようなコミュニケーションを実現し，テ

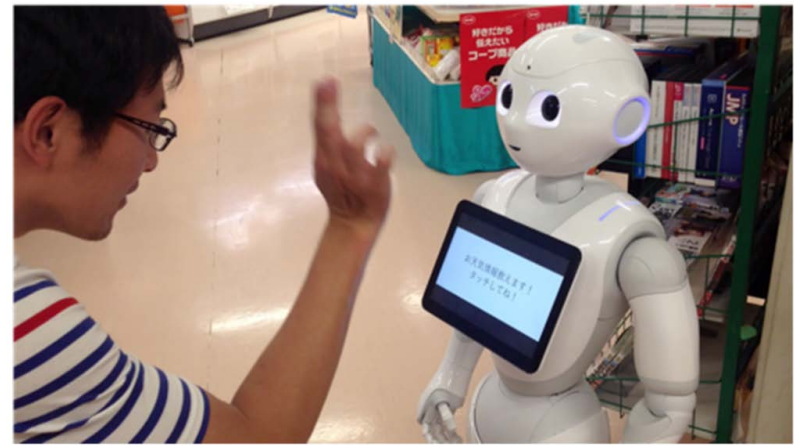

図 1 Pepper を用いたサービスの実証実験例 [12]

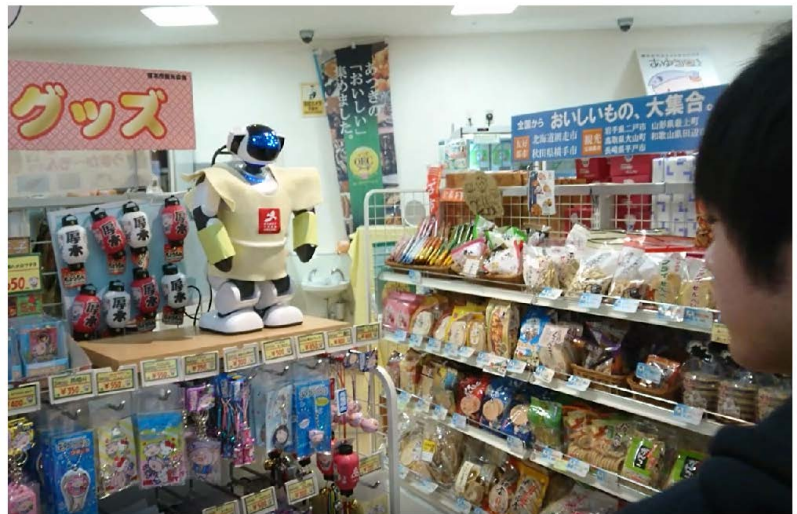

図 2 PALRO を用いたショッピングセンターにおける情報推 薦の実証実験例 [15]

レワークなどに用いられている. OriHime-D は, 遠隔で接客 やものを運ぶ業務などを行うことができ，カフェでの実証実験 が行われている。

紙面の関係上，多くを紹介できないが，ヴイストンの「Sota」 [18] やシャープの RoBoHoN [19] も様々なシーンで用いられ, ハウステンボスの「TELLBO」[20]やユカイ工学の「BOCCO emo」[21] など, 積極的に触りたくなるようなデザインも増え てきた。

\section{2 コミュニケーションロボットの機能と課題}

上述のように，コミュニケーションロボットは，人との直接 的なコミュニケーションだけで無く，人と人を繋ぐコミュニ ケーションを間接的に支援する。本稿では, 近年のコミュニ ケーションロボットの利用シーンを (1) テレイグジスタンス支 援，（2）個人特化支援，（3）場所依存支援，（4）一般情報支援に 分類する。

テレイグジスタンス支援では，テレワークや単身赴任，入院 など, 離れて暮らす人のために用いられ, 人と人のコミュニ ケーションを自然に繋ぐ。話した内容や顔の表情などにしたが い，相手側のロボットがジェスチャや領きなどの表出を行い， あたかも本人と会話を行っているかのような演出を行うインタ フェースの役割を果たす。離れた人々がメッセージのやりとり を気軽に行えるように，子供やペットをイメージした親しみ やすいデザインが増えている，実際，長期間に渡り，使用する と，その人のように思えてくるという意見もあり，非常に有意 
義な社会実装である。一方で，これらのロボットの多くは，才 フライン時に動作や会話などが無いため, オフライン時のコ ミュニケーションのデザインをどのように行うかが課題の一つ である.

個人特化支援では，独居高齢者などを対象とした日常生活に おける見守りや情報支援が行われる。例えば，コミュニケー ションロボットとの会話などを通して収集された個人情報に基 づき，適切な発話内容が選択されたり，さらには，スマートデ バイスのコンテンッとの連携に基づき，通院や各種予定の通知 などを行う $[22,23]$. しかしながら，個人情報を利用した発話 には，プライバシーを伴う内容もあるため，個人宅に来客など があった際の発話内容の取捨選択方法なども重要な課題の一つ である.

場所依存支援では，空港や観光地，美術館，ショッピングセ ンターなど公共空間での情報支援が主な業務である $[24,25]$. 現在は，デジタルサイネージやタッチパネルを用いたインフォ メーションサービスの置き換えが中心であり，利用者の目的地 までの物理的な誘導支援などは限定的に用いられている．情報 支援に関して，電車やバスの発車時刻の案内や天気や災害情報 の案内は，比較的，容易に行える。実際，イベントの開催情報 案内など, Linked Open Data（LOD）との連携が進みつつある 反面，当該施設の案内や近隣で公開されている情報の多くが PDF であるため, ロボットの発話用としての再利用が困難で あるというコンテンツの問題がある。例えば，美術館や科学館 で用いられている音声ガイドレシーバーの音声情報は, 多くの 場合，コンテンツが長く，インタラクティブなロボットとのコ ミュニケーション用には設計されていない。もし，各種説明用 の文章・音声データが複数の短めの文章で構成され, さらに, 関連キーワードの夕グ付け（属性付与）ができるのであれば, 受付用ロボットの質疑や順路に沿った案内だけでなく，美術館 や科学館の案内 web ページ上で, チャットボットを用いた質 問コーナーにも活用できる。また，近隣の商店街も，このよう なコンテンツを利用することができれば，様々なサービスと連 携できる（図 3)。さらに，利用者の属性にあわせて，話し方さ えも適応的に変えることができれば，自然なコミュニケーショ ンを実現できる。これからは，様々な用途を考慮したコンテン ツのデザインを行う必要があり，コンテンツのデザイン次第で は，個人を対象とした支援だけでなく，地域コミュニティの支 援にも繋げることができる [26, 27].

一般情報支援では，スマートスピーカー的な役割が期待さ れる。個人特化支援とは異なり，例えば，不特定の利用者から 「明日の天気は?」や「エアコンをつけて」などの問いかけに 対し，パッシブに機能し，ロボット側からは，挨拶などの一般 的な会話以外, アクティブにコミュニケーションを行わない. 音声対話による最低限必要な情報支援を求めるのであれば，口 ボットとしての物理的な存在感は不要であり,コミュニケー ションロボットはスマートデバイスの置き換え的な存在とな り，そのような観点からコミュニケーションロボットが不要と まで言われている。しかしながら，コミュニケーションロボッ 卜は，領きやジェスチャなど，ノンバーバルな物理的反応を伴 うため, 無機質感が少なく, 親しみやすい. したがって, 利用

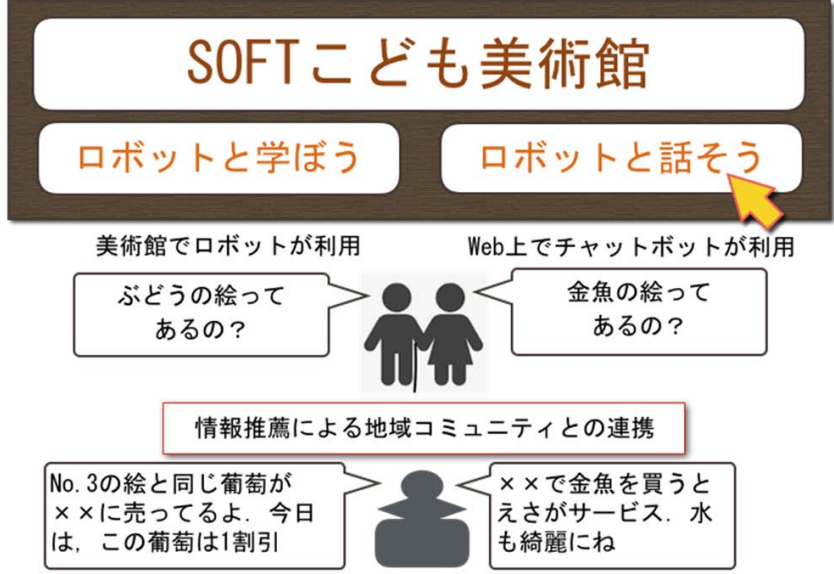

図３コミュニケーションロボットとコンテンッのデザイン

者の嗜好にあわせた選択にゆだねるカタチで，様々な形状のス マートスピーカーとコミュニケーションロボットの商品化が展 開されていくと考えられる

\section{3. ロボットのコミュニケーション}

\section{1 コミュニケーション技術}

前章では，コミュニケーションロボットの社会実装の現状に ついて説明し, 利用シーンを分類した上で今後の課題について 検討したが，本章では，自然なコミュニケーションを実現する ために必要な理論と技術について考える，前にも述べたが，コ ミュニケーションロボットの普及に伴い, 時間と場所, 経験を 共有するロボットに対し, 利用者自身, つまり, 自分という存 在をも理解して欲しいと期待してしまうかもしれない。例え ば,ペットの犬は，飼い主と経験を共有することにより少しず つ学習が進み, その空間に拈ける互いの共存・共生のあり方を 調整しつつ，社会的な関係性を構築する。そのような関係性の 構築には互いの存在を理解し合うことが不可欠であろう

現在，深層学習が社会に深く浸透し，我々は，音声・画像認 識技術をはじめ，日常生活においてその恩恵を受けている。画 像・音声認識技術の多くは, 何らかの特徴を抽出し, それが最 終的に何であるか, 人間が理解可能な言語ラベルとして出力す る. 一般に, シンボルグラウンディング問題は, 記号システム 内の記号（ここでは，言語ラベル）と実世界における意味を結 びつけることができるかという問題である [28-30]. 何らかの 言語ラベルを最終的に出力する認識技術は, シンボルグラウン ディング問題を解いていると言えるのであろうか. 例えば, 人 間がコミュニケーションロボットにリンゴを見せて，ロボッ トから「そのリンゴ，おいしそうだね」と返答があり，人間が 「そうだね」と話したとしよう。現在，このような会話は，難 なく実現できる。コミュニケーションロボットやチャットボッ ト, スマートスピーカー (以下, これらをまとめて, スマート エージェントと呼ぶことにする）は過去の膨大な会話データか ら学習した発話システムを用いて，意味が通じそうな発話を行 う。つまり, スマートエージェントは, 意味を理解していると は言いがたく，単に人間が理解できそうな意味を含む発話をし ているに過ぎない。スマートエージェントの音声・画像認識シ 
ステムは，日々，膨大なデー夕を吸収し，人々が利用すること によって, さらに学習し続ける。 それを利用するスマートエー ジェントとコミュニケーションを行っている人間は, いった い何と話をしているのか, 考えさせられる.もちろん, スマー トエージェントは, 利用者の個人情報も利用し, コミュニケー ションを通して利用者の嗜好などを抽出し, あたかも利用者に 適応しているように思える，しかしながら，利用者である自分 という存在を理解しているのかはよくわからない，逆に考え ると, どのような要素があれば, 利用者である自分という存在 を理解していると思えることができるのか, 次の節で考えて みる。

\section{2 コミュニケーションにおける階層性と意図共有}

新学術領域「共創的コミュニケーションのための言語進化 学」では,「階層性」と「意図共有」を 2 つ柱として, 言語 進化 (共創言語進化) のメカニズムを解明しようと試みてい る [29, 30]. 例えば，日本語で「魚の赤いカバン」が意味する 内容は, 図 4 に示すように, 少なくとも 3 種類の解釈が考えら れよう. 基本的に 3 つ以上の記号が組み合わされる場合, 構造 依存性が生じ, 複数の階層構造の可能性が生じてしまう [30]. また，図 5 のように,「魚の赤いカバンを取って」と言われれ ば，我々は，どれを選択すべきか，迷ってしまうであろう。そ れは, グライスの 4 つの格率のいずれかが満たされていないか

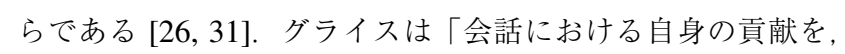
そのときどきに参加している会話のやりとりの中で合意されて いる目的や方向性にあうようにせよ」という協調原理と以下の 4 つの格率を提案した。

・量の格率：会話の目的に必要な情報量は与え, それ以上は, 与えないようにせよ

・質の格率：真であることを言うようにせよ

・関係性の格率：関連性のあることを言うようにせよ

・様態の格率：わかりやすい言い方をするようにせよ

受け手は, 話し手が上述の 4 つの格率に従って情報提供して いると期待している. 先ほどの例では, 量の格率に従うと「赤 い絵のカバン」と言えば十分であろうし, 関係性の格率に従え ば「机の上のカバン」と言えば一つに特定できる.

スペルベルとウィルソンの関連性理論 [31] では, 話し手や 聞き手が関わっている環境を「認知環境」とし, 話し手の認知 環境に近い形に聞き手の認知環境を拡張することで「相互認知 環境」として共有されると考えられている. 聞き手が認知して いる環境情報に基づき，伝えたいことをより少ない言葉で適切 に伝わるように表現している（関連性の伝達原則）。話し手は, 時々刻々と認知環境の想定を更新しながら, 聞き手とのコミュ ニケーションを進める. したがって, この例において, 机の上 を相互認知環境として共有するために，まず「机の上をみて」 と言った後に,「カバンを取って」と言えばよい. しかし，こ のコミュニケーションロボットに「カバンを取って」とお願い すれば，把持するだけで動かないかもしれない，ここで，我々 が期待している「取って」という言葉には, 単に「取る」とい う行為だけでなく，「持ってくる」という行為も暗に含まれて

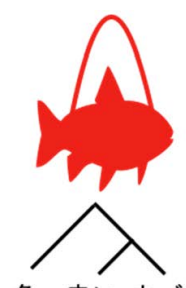

魚 赤いカバン

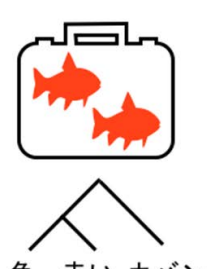

魚 赤い カバン

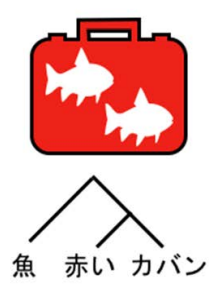

魚 赤いカバン
図4「魚の赤いカバン」の解釈における階層性

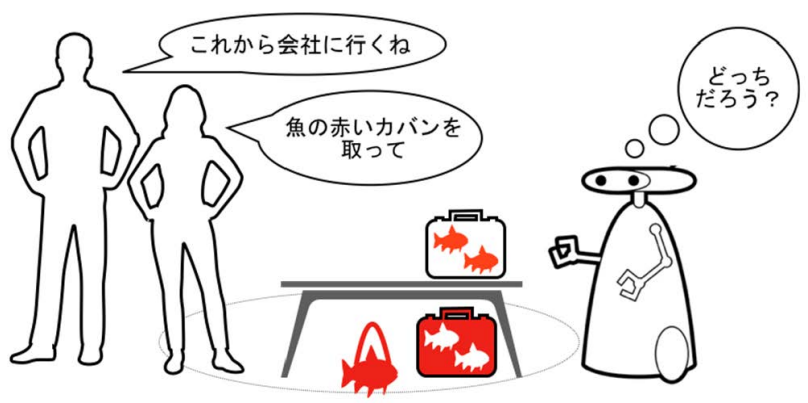

図 5 ロボットとの意図共有

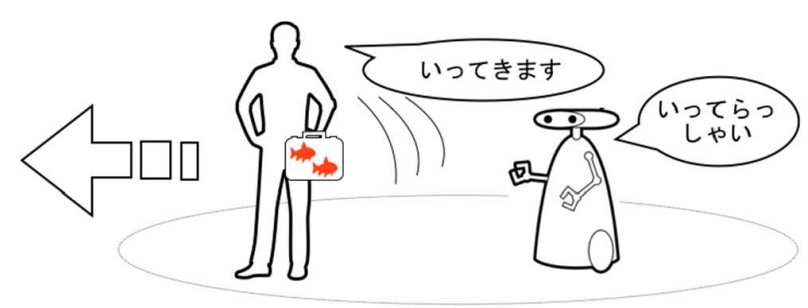

図 6 過去把持と未来予持

いる.つまり，このロボットに対し様態の格率が満たされてい ない. したがって，コミュニケーションロボットには，「机の 上のカバンを取って, 持って来て」とお願いすべきであろう. 我々が行っている円滑なコミュニケーションでは, 実に多くの ことを潜在的に考慮していることがわかる.

\section{3 コミュニケーションにおける記憶}

円滑なコミュニケーションを行うためには, 4 つの格率や関 連性理論を考慮した上で, 過去の経験も考慮する必要がある. 例えば, 図6のように, 翌日に「カバンを取って」とお願いす れば, 共有された過去の経験の記憶にしたがい, 昨日と同じカ バンを選択できるだろう. 現象学 [32]では, 経験において, 何 かが「意識に残る」意識のされ方を過去把持と呼び, 自覚せず に予測している意識の働きを未来予持と呼ぶ. 人間のもつ想定 とは，今に直属する過去把持と未来予持を含んでおり，コミュ ニケーションにおいて, 未来予持にあわせて互いの認知環境を 拡大・縮小し, 相互認知環境として共有していると考えられる. 円滑なコミュニケーションを行うためには, このような能力を コミュニケーションロボットにも持たせる必要があろう.

一般に, 記憶は時間的な観点から短期記憶と長期記憶に分け られ，長期記憶は陳述記憶と非陳述記憶に分類される [33]. 陳 述記憶は, さらにエピソード記憶と意味記憶に分類される. 人 間との円滑なコミュニケーションを実現するためには, エピ 
ソード記憶に基づく経験の共有が重要になる，例えば，筆者ら は，人間との円滑なコミュニケーションを実現するために，エ ピソード記憶に基づく学習方法を提案してきた [34]. 具体的に は，各種センサネットワークデバイスを用いて得られた人間の 状態や物体に関する情報から人間の認知環境を推定し，人間が 行う行為と物体との対応関係を学習し，これらの学習結果を次 のコミュニケーションに反映する（図 7).

\section{4 エピソード記憶に基づくコミュニケーション}

本研究では, 学習された行為と物体の関係性に基づき, 人間 の次の行動を予測するために，ナイーブベイズを用いた手法を 提案した，実験例として，ロボットが想定する人間の認知環境 内の物体の情報を用いて机の上にある物体を認知した後に部屋 の中から何を選択するのかを予測し，推定した認知環境と予 測に基づくコミュニケーションを紹介する。ここでは，実験の 簡単化のために，図 8 における実験環境内の物体は，事前に Convolutional Neural Network（CNN）にて認識できるように 学習を行った。また, OpenPose [35] を用いて RGB 画像を入力 として全 25 点の身体部位の情報を獲得し，CNN を用いて，人 間の向きの推定と行動推定を行った。ここで，人間の向きに合 わせて，人間の認知環境内にあるであろう物体の認識を行い, これを想定として扱い，過去に人間が扱った物体の時系列の関 係性からナイーブベイズを用いて次の行為の予測を行う（未来 予持).

エピソード記憶に基づくコミュニケーションの有効性を示 すために，以下のような実験を行った。具体的なシナリオとし て，被験者が州宅した際「「インを買ってきたよ」と，ロボッ トにワインボトルを見せて，グラスを取りに左側のキャビネッ トの方に向かう。ここで，相互認知環境を介したコミュニケー ションに関して，以下の 3 種類の条件で実験を行った

（実験条件 1）未来予持された想定と一致する場合 （実験条件 2）未来予持された想定と一致しない場合

（実験条件 3）未来予持された想定における物体が認知環境内 に無い場合

実験条件 1 では，ワイングラスを取って，座椅子に座ると， ロボットは,「ワイングラスで飲むと美味しいよね」と発話し た。実験条件 1 での学習により経験が更新された後，次に，実 験条件 2 として，上述のように，ロボットにワインボトルを見 せた後, キャビネットにグラスを探しに行く．しかしながら， 被験者は，ワイングラスでは無く，コップを取ると，未来予持 された想定と異なるため,「コップで飲むなんて珍しいね」と 発話した。最後に, 実験条件 3 として, ロボットにワインボト ルを見せた後，キャビネットにグラスを探しに行くが，グラス の探索に時間がかかり，未来予持された想定における物体（ワ イングラス）が認知環境内に存在しないため, ロボットは,「ワ イングラスなら反対の棚にあるよ」と発話した。このように， 利用者と共有された経験をエピソード記憶として学習し，それ を活用することにより，コミュニケーションが円滑に進む。た だし，このような実験結果を示しても，シンボルグラウンディ ング問題を解いているのかどうかは明確にはわからない。記号

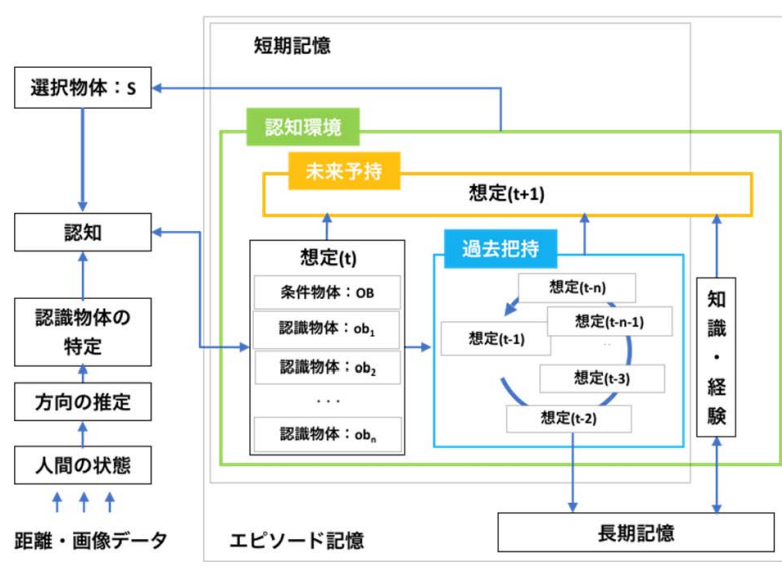

図 7 エピソード記憶に基づく学習

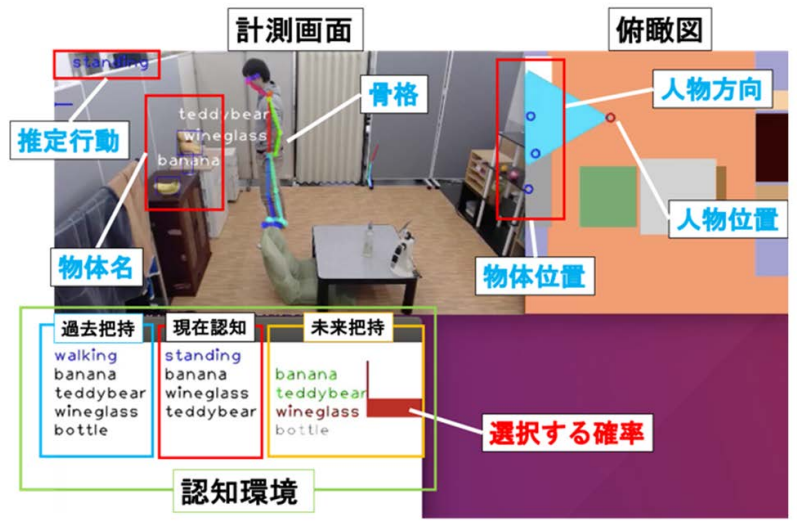

図８エピソード記憶に基づくコミュニケーションの実験例

の意味とは何かを明確に定義することはできないが，少なくと も経験を共有することにより，意図共有はできそうである。

\section{4. さいごに}

本稿では，まず，コミユニケーションロボットの市場動向を 紹介し, RaaSの現状について概観した上で, コンテンツのデ ザインに関する問題やシンボルグラウンディング問題など，コ ミュニケーションロボットの社会実装と運用の難しさについ て説明した．特に，コミュニケーションにおける構造依存性の 問題は, 我々人間も理解に苦しむシーンが多々ある。コミュニ ケーションロボットを社会実装していく上で, これらの問題も 知能化技術の高度化により少しずつ改善できるかもしれない が, 様々なコミュニケーションロボットが次々と商品化されて いくのは間違いない.

最後に，コミュニケーションについて，別の観点から考えて みることにする。1950 年代にテレビを中心としたメディア革 命がおこったとき，「メディアとは身体拡張である」とする身 体拡張説を唱えたマクルーハンは，「人間が使う技術というも のは，身体の活動の延長であり，メデイアを使用することで, 人間が行いうる記号活動の範囲は拡大する」と述べた $[36,37]$. さらに, マクルーハンは, メディアは「メッセージ」であると 定義した上で，「新聞であれ，テレビであれ，人々が社会の情 報に接するとき，その内容としてのメッセージを受け取ってい 
るので無く，そういうメデイアに接することで生活のスタイル を作っている。情報を知ることにより，それに摇さぶられる快 感を目指している」と述べ，メディアは「マッサージ」である と言い換えた。 まさに現在の状況そのものである。また，我々 人間は，SNS を通して，互いに新しい情報を創出し，共有する とともに，スマートエージェントは，その情報から学習し続け ている.

現在，我々が利用するメディアは，Virtual Reality（VR）と して融合され，VRは，ネットゲーム内でのプレイヤ間の連携 だけで無く，ダンスパーティ [38] などの社会的なイベントも 展開されており，今後は，疑似恋愛 [39]までも演出してしまう かもしれない. 日々, メディアは進化・成長し, 近い将来, ス マートエージェントが利用者の代わりにイベントに参加し, 疑 似恋愛までもこなしてくれるかもしれない.

グリーンフィールド [40] が予測したように, VRの中で多く のことができるようになり，実環境では自分の代わりにコミュ ニケーションロボットが，会話の間を紡ぎつつ，相手の意図を 理解し，こちらの意図を伝え，半自律的に交渉を成立させ，さ らに，人工知能は，その交渉自体をも学習し，次の交渉に備え る，そんな時代が近づいている。

人工知能は，ありとあらゆるデー夕を飲み込もうとする が，質の高いデータを選ばないと，質の高い学習はできない. Human-in-the-loop [41] では，専門的な知識を持つ人間が人工 知能と協力しながら学習を展開していく人間参加型の機械学習 の重要性を示唆し、コミュニケーションロボットは, そのイン タフェースになり得る。また，半教師あり学習 [42]では，自 らデー夕を選別しながら教師デー夕を生成し，学習を進める。 さて, 学習し続けるスマートエージェントの挙動は, StarTrek に出てくるBorg [43]に似ているように思える，Borgは，全 宇宙の文明，文化，知能を吸収同化しょうとする，Borgに所 属する生命体は「ドローン」と呼ばれ，ドローンには個人とい う概念がなく，集合体という共有意識をもって活動し，脳に直 結された通信装置で常に情報を共有している。ドローン自体 は，集合体全体の意思決定に従い行動するため，個別に意思決 定や判断を行わない，我々，現在の人間は，集合体として物理 的に結合されてはいないが，協調フィルタリングの結果に基 づく推薦情報を，深く考えること無く，そのまま利用してい る。また，スマートエージェントから，日々の生活に有益な情 報を受け取り，それに従っている。つまり，集団で全体の意思 決定を生み出し, それに束縛される。この意思決定の過程は, Borg のような挙動であり, 人工知能がイニシアティブをとっ た Human-in-the-loop もまた, Borg のような挙動になるのかも しれない. Borg のエピソードで, 一番, 興味深かったのは, ピ カード艦長が同化から戻ったとき，「Borg の中では意思決定か ら解放され，心地よかった」というようなことを言ったことで ある。決断することや取捨選択には，苦痛を伴うことが多い. コミュニケーションロボットは，人間と経験を共有することに より，この苦痛を共有してくれるのか，この苦痛を和らげてく れるのか，考えさせられる。近い将来，コミュニケーションロ ボットの存在意義を考えつつ, 経験が共有できることを活かし た自然なコミュニケーションが実現できることを期待する.

\section{謝辞}

本稿の執筆にあたって，橋本智己先生には，有益な助言をい ただいた。また，本稿の階層性と意図共有に関する議論は，新 学術領域「共創的コミュニケーションのための言語進化学」に おける議論から多くの知見を得たものであり, 関係諸氏に謝意 を表する。

\section{参 考 文 献}

[1] A. M. Turing: "Computing Machinery and Intelligence," Mind, Vol.59, pp. 433-466, 1950.

[2] 人工知能学会: チューリングテストと中国語の部屋. https: //www.ai-gakkai.or.jp/whatsai/AItopics3.html [accessed Sep. 5, 2019]

[3] International Federation of Robotics: WR 2018 Service Robots press release Japanese. https://ifr.org/downloads/press2018/ 2018-10-18_PR_IFR_WR_2018_Service_Robots_Jap.pdf [accessed Oct. 18, 2018]

[4] 経済産業省: ロボット産業市場動向調査結果, 2013.

[5] IDC Japan 株式会社: 国内サービスロボット/ドローン ユーザー利用動向調査結果. https://www.idcjapan.co.jp/Press/ Current/20180822Apr.html [accessed Apr. 8, 2019]

[6] 2018 年に国内で開発されたサービスロボットの動向に関す る調査結果を発表. https://www.asratec.co.jp/2019/01/31/23946/ [accessed Sep. 5, 2019]

[7] 総務省: 平成 30 年版情報通信白書. http://www.soumu.go.jp/ johotsusintokei/whitepaper/ja/h30/pdf/30honpen.pdf [accessed Sep. 5, 2019]

[8] IBM: IBM Watson. https://www.ibm.com/watson/jp-ja/ [accessed Sep. 5, 2019]

[9] 株式会社マックスマウス: 頼友. https://aiyoritomo.com [accessed Sep. 5, 2019]

[10] R. Baheti and H. Gill: "Cyber-physical Systems," The Impact of Control Technology, Vol.12, No.1, pp. 161-166, 2011.

[11] ソフトバンクロボティクス: Pepper for Biz. https://www. softbankrobotics.com/jp/product/biz2/ [accessed Apr. 8, 2019]

[12] 木村慶, 大西佑城, 下川原 (佐藤) 英理, 山口亨: “対話ロボット による情報推薦とインタラクションがもたらすユーザ状態の変 化獲得,”第 18 回計測自動制御学会システムインテグレーショ ン部門講演会, pp. 1881-1884, 2017.

[13] Aeolus Robotics (アイオロス・ロボティクス) .https://aeolusbot. com/our-robots/ [accessed Apr. 8, 2019]

[14] PALRO. https://palro.jp [accessed Sep. 5, 2019]

[15] 杉本昇大, 大保武慶, 久保田直行: “店舗案内のための没入感を高 めるマルチロボットコミュニケーション,”ロボティクス・メカ トロニクス講演会 2019 講演論文集, 1A1-C01, 2019.

[16] Double 2 遠隔プレゼンスシステム. http://www.nihonbinary.co. jp/Products/Robot/double.html [accessed Sep. 5, 2019]

[17] オリイ研究所. http://orylab.com/ [accessed Apr. 12, 2019]

[18] Sota. https://sota.vstone.co.jp/home/ [accessed Sep. 5, 2019]

[19] RoBoHoN. https://robohon.com/ [accessed Sep. 5, 2019]

[20] TELLBO. https://www.huistenbosch.co.jp/event/tellbo-robot/ [accessed Sep. 5, 2019]

[21] BOCCO emo. http://www.bocco.me/emo/ [accessed Sep. 5, 2019]

[22] J. Szeles, N. Kubota, and J. Woo: "Weather Forecast Support System Implemented into Robot Partner for Supporting Elderly People using Fuzzy Logic," Proc. of 2017 Joint 17th World Congress of Int. Fuzzy Systems Association and 9th Int. Conf. on Soft Computing and Intelligent Systems, pp. 1-5, 2017.

[23] W. Woo, K. Wada, and N. Kubota: "Robot Partner System for Elderly People Care by using Sensor Network," Proc. of 2012 4th IEEE RAS \& EMBS Int. Conf. on Biomedical Robotics and Biomechatronics, pp. 1329-1334, 2012.

[24] Y. Shimizu, S. Yoshida, J. Shimazaki, and N. Kubota: "An Interactive Support System for Activating Shopping Streets using Robot Partners in Informationally Structured Space," Proc. of 2013 IEEE 
Workshop on Advanced Robotics and Its Social Impacts, pp. 70-75, 2013.

[25] S. Sun, T. Takeda, H. Koyama, and N. Kubota: "Smart Device Interlocked Robot Partners for Information Support Systems in Sightseeing Guide," Proc. of 2016 Joint 8th Int. Conf. on Soft Computing and Intelligent Systems and 17th Int. Symp. on Advanced Intelligent Systems, pp. 586-590, 2016.

[26] 久保田直行: “人間共生システムに扔けるコミュニケーションの デザインからエクスペリエンスのためのデザインへ,”知能と情 報（日本知能情報ファジィ学会誌）, Vol.27, No.6, pp. 182-192, 2015.

[27] 久保田直行: “コミュニティとシステム,”知能と情報（日本知能 情報ファジィ学会誌）, Vol.29, No.4, pp. 120-127, 2017.

[28] S. Harnad: "The Symbol Grounding Problem," Physica D: Nonlinear Phenomena, Vol.42, Issues 1-3, pp. 335-346, 1990.

[29] 共創的コミュニケーションのための言語進化学. http:// evolinguistics.net/ [accessed Sep. 5, 2019]

[30] 橋本敬: “コミュニケーションの 3 つのレベルにおける接地・脱 接地,”日本認知科学会第 32 回大会, pp. 116-119, 2015.

[31] D. Sperber and D. Wilson: Relevance - Communication and Cognition, Blackwell Publishing Ltd., 1995.

[32] 山口一郎: 実存と現象学の哲学, 放送大学, 2009.

[33] L. R. Squire and S. M. Zola: "Structure and Function of Declarative and Nondeclarative Memory Systems," Proc. of the National Academy of Sciences, Vol.93, No.24, pp. 13515-13522, 1996.

[34] 久保田直行: “コミュニケーションロボットのための認知環境に 基づく行動認識,”画像ラボ, 2019 (予定).

[35] Z. Cao, T. Simon, S. E. Wei, and Y. Sheikh: "Realtime Multiperson 2D Pose Estimation using Part Affinity Fields," Proc. of 2017 IEEE Conf. on Computer Vision and Pattern Recognition (CVPR), pp. 1302-1310, 2017.

[36] M. McLuhan: Understanding Media: The Extensions of Man, McGraw-Hill, 1964.

[37] 石田英敬: 現代思想の地平, 日本放送出版協会, 2005.

[38] バーチャル空間での DJ ライブ. http://wavexr.com [accessed Sep. 5, 2019]

[39] 伊藤匠: VR なんて絵空事. http://renga.com/anzai/lab/esoragoto/ [accessed Sep. 5, 2019]

[40] スーザン・グリーンフィールド: 未来の私たち, NPO 科学技術 社会研究所, 2008.

[41] The Power of Human-in-the-Loop: Combine Human Intelligence with Machine Learning. https://blogs.technet.microsoft.com/ machinelearning/2016/10/17/the-power-of-human-in-the-loopcombine-human-intelligence-with-machine-learning/ [accessed Sep. 5, 2019]

[42] 鈴木大慈: “機械学習の概要, ”応用数理, Vol.28, No.1, pp. 32-37, 2018.

[43] Borg. https://intl.startrek.com/database_article/borg [accessed Sep. 5, 2019]

(2019年 6 月 20 日 受付)
[問い合わせ先］

テ191-0065 東京都日野市旭が丘 6-6

首都大学東京大学院 システムデザイン研究科

久保田 直行

E-mail: kubota@tmu.ac.jp

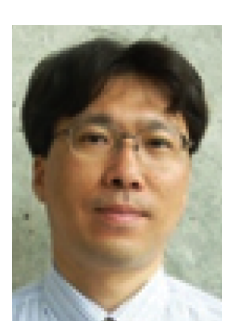

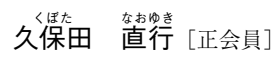

1992 年大阪教育大学教育学部教養学科卒業. 1994 年北海道大学大学院工学研究科情報工 学専攻修士課程修了. 1997 年名古屋大学大 学院工学研究科マイクロシステム工学専攻博 士後期課程修了. 博士 (工学) . 1997 年大阪 工業大学工学部機械工学科助手, 1999 年同 講師. 2000 年福井大学工学部知能システム工 学科助教授, 2004 年東京都立大学大学院工学 研究科機械工学専攻助教授となり, 2005 年首 都大学東京システムデザイン学部ヒューマン メカトロニクスシステムコース准教授, 2012 年同教授, 2018 年首都大学東京システムデザ イン学部機械システム工学科教授, 現在に至 る。 その間, 2002 年から 2008 年まで科学技 術振興機構研究員兼任. 英国王立協会客員教 授（ポーツマス大学, 2007 年)。韓国ソウル 国立大学客員教授（2009年から 2012 年）他. IEEE, 日本ロボット学会, 計測自動制御学会, システム制御情報学会, 日本機械学会, などの 会員. 